\title{
MEMAHAMI MEKANISME PASAR DALAM EKONOMI ISLAM
}

\section{Sukamto}

\begin{abstract}
Abstrak
Pasar adalah sebuah mekanisme pertukaran produk baik berupa barang maupun jasa yang alamiah dan telah berlangsung sejak peradaban awal manusia. Islam menempatkan pasar pada kedudukan yang penting dalam perekonomian. Praktek ekonomi pada masa Rasulullah SAW dan Khulafaurrasydin menunjukkan adanya peranan yang besar dalam pembentukan masyarakat Islam pada masa itu. Rasulullah SAW sangat menghargai harga yang dibentuk oleh mekanisme pasar sebagai harga yang adil (price intervencion) seandainya perubahan harga terjadi karena mekanisme pasar yang wajar yaitu hanya karena pergeseran permintaan dan penawaran. Namun, pasar di sini mengharuskan adanya moralitas dalam aktivitas ekonominya, antara lain; persaingan sehat dan adil (fair play), kejujuran (honesty), keterbukaan (transparancy), dan keadilan (justice). Jika nilai ini ditegakkan maka tidak ada alasan dalam ekonomi Islam untuk menolak harga yang terbentuk oleh mekanisme di pasar.
\end{abstract}

Kata Kunci: Pasar, Harga, Ekonomi Islam

Pembahasan ini akan berusaha menjelaskan bagaimana Rasulullah SAW menghargai mekanisme yang terjadi di pasar sebagi sunatullah yang harus dihormati. Pandangan tentang pasar dan harga dari beberapa pemikir besar muslim seperti Abu Yusuf, Al-Ghazali, IbnuTaimiah dan Ibnu Khaldun juga diungkap. Pemikiran mereka tentang pasar ternyata layak dikaji dan telaah mengingat pasar merupakan parameter perekonomian umat. Pemikiran mereka tentu saja merupakan khazanah intelektual yang berharga pada masa kini dan masa yang akan datang.

Pada masa Rasulullah SAW dan Khulafaurasyidin, pasar memegang peranan penting dalam perekonomian. Bahkan Rasulullah SAW pada masa awalnya terkenal sebagai pebisnis yang berhasil. Pada usia tujuh tahun, beliau telah mengadakan perjalanan perdagangan bersama pamannya Abu Talib ke negeri Syam. Jiwa bisnis beliau mulai mengkristal semenjak sering pergi ke negeri Syam.

Kemudian, sejalan dengan usianya semakin dewasa, Nabi Muhammad SAW semakin giat berdagang, baik dengan modal sendiri, ataupun bermitra dengan orang lain. Kemitraan, baik dengan sistem mudharabah atau musyarakah,

jsh Jurnal Sosial Humaniora, Vol 5 No.1, Juni 2012 
dapat dianggap cukup populer pada masyarakat Arab pada waktu itu. Salah satu, mitra bisnisnya adalah Khadijah seorang pengusaha yang cukup disegani di Mekkah, yang akhirnya menjadi istri beliau. Berkali-kali Muhammad SAW terlibat urusan dagang ke luar negeri (Syam, Suriah, Yaman dan lain-lain) dengan membawa modal dari Khadijah. (Hamsyari, 1985: 85)

Muhammad SAW adalah seorang pedagang profesional dan selalu menjunjung tinggi kejujuran, ia mendapat julukan al-amin (yang terpercaya).

Setelah menjadi rasul, Nabi Muhammad SAW memang tidak lagi menjadi pelaku bisnis secara aktif karena situasi dan kondisinya yang tidak memungkinkan. Pada saat perkembangan Islam di Mekkah Rasulullah SAW dan masyarakat muslim mendapat gangguan dan teror yang berat dari masyarakat kafir Mekkah sehingga perjuangan dan dakwah menjadi prioritas utamanya. Ketika masyarakat muslim telah berhijrah ke Madinah, peran Rasulullah SAW bergeser menjadi pengawas pasar atau muhtasib. Beliau mengawasi jalannya pasar di Madinah dan sekitarnya agar tetap dapat berlangsung secara islami.

Pada saat itu mekanisme pasar sangat dihargai. Beliau menolak untuk membuat kebijakan penetapan harga manakala tingkat harga di Madinah pada saat itu tiba-tiba naik sepanjang kenaikan terjadi karena kekutan permintaan dan penawaran yang murni, yang tidak dibarengi dengan dorongan-dorongan monopolistik dan monopsonistik, maka tidak ada alasan untuk tidak menghormati pasar. Pada saat itu para sahabat berkata:

“Wahai Rasulullah tentukan harga untuk kita!". Beliau menjawab"Allah SWT sesungguhnya adalah penentu harga, penahan, pencurah serta pemberi rizki. Aku mengharapkan dapat menemui Tuhanku dimana salah sorang dari kalian tidak menuntutku karena kezaliman dalam masalah darah dan harta."

Dalam hadist di atas jelas menyatakan bahwa pasar merupakan hukum alam (sunnatullah)yang harus dijunjung tinggi. Tak seorang pun secara individual dapat mempengaruhi pasar, sebab pasar adalah kekuatan kolektif yang menjadi ketentuan Allah. Pelanggaran terhadap harga pasar, misalnya penetapan harga dengan cara dan karena alasan yang tidak tepat, merupakan suatu ketidakadilan (zulm/injustice) yang akan dituntut pertanggungjawabannya dihadapan Allah. 
(Enginer, 1999: 137) Sebaliknya, dinyatakan bahwa penjual yang menjual dagangannya dengan harga yang adil laksana orang yang berjuang dijalan Allah (jihad fi sabilillah), sementara yang menetapkan sendiri dengan motif aniaya termasuk sebuah perbuatan ingkar kepada Allah. Dari Ibn Mughirah terdapat suatu riwayat ketika Rasulullah SAW melihat seorang anak laki-laki menjual makanan dengan harga yang lebih tinggi dari harga pasar. Rasulullah SAW bersabda:

"Orang-orang yang datang membawa barang ke pasar ini laksana orang berjihad fisabilillah, sementara orang-orang yang menaikkan harga (melibihi harga pasar) seperti orang yang ingkar kepada Allah."

Penghargaan Islam terhadap mekanisme pasar berdasarkan pada ketentuan Allah bahwa perniagaan harus dilakukan secara baik dengan rasa suka sama suka ('antaradin minkum/mutual goodwill). Dalam Al-Qur'an dinyatakan dalam surat An-Nisa: 29):

"Wahai orang-orang yang beriman janganlah kamu saling memakan harta sesamamu dengan cara batil, kecuali dengan jalan perniagaan yang berlaku dengan suka sama suka diantara kamu. Dan janganlah kamju membunuh dirimu, sesungguhnya Allah Maha Penyayang kepadamu."

Agar mekanisme pasar dapat berjalan dengan baik dan memberikan mutual goodwill bagi para pelakunya, maka nilai moralitas mutlak harus ditegakkan. Secara khusus, nilai moralitas yang mendapat perhatian penting dalam pasar adalah persaingan yang sehat, kejujuran, keterbukaan dan keadilan. Nilai moralitas ini memiliki akar yang kuat dalam ajaran Islam, sebagaimana dicantumkan dalam berbagai ayat Al-Quran. Untuk itulah, Rasulullah SAW telah menetapkan beberapa larangan terhadap praktek bisnis yang dapat mengganggu mekanisme pasar yang islami.

\section{Pandangan Ekonom Muslim}

Pasar telah mendapatkan perhatian istemewa dari para ulama klasik seperti Abu Yusuf, Al-Ghazali, Ibnu Taimiyah, dan Ibnu Khaldun. Pemikiran tentang pasar tidak saja mampu memberikan analisis yang tajam tentang apa yang terjadi pada masa itu, tetapi tergolong modern untuk masa sekarang. Banyak dari pemikiran mereka baru dibahas oleh ilmuwan barat beratus-ratus tahun kemudian.

jsh Jurnal Sosial Humaniora, Vol 5 No.1, Juni 


\section{Mekanisme Pasar Menurut Abu Yusuf (731-798 M)}

Pemikiran Abu Yusuf tentang pasar dapat dijumpai dalam karyanya alkharaj. Selain membahas perpajakan dan anggaran negara yang menjadi pedoman kekhalifahan Harun Al-Rasyid di Bagdad, buku tersebut juga membicarakan beberapa prinsip dasar mekanisme pasar. (Al-Audhi, 1987: 119). Tulisan pertamanya menguraikan tentang naik turunnya produksi yang dapat mempengaruhi harta. Ia telah menyimpulkan bekerjanya hukum permintaan dan penawaran dalam pasar.

Mayarakat luas pada masa itu memahami bahwa harga sesuatu hanya ditentukan oleh penawarannya. Dengan kata lain, bila hanya tersedia sedikit barang, maka harga akan mahal, sebaliknya jika tersedia banyak barang, maka harga akan murah. Mengenai hal ini Abu Yusuf berkata,'Tidak ada batasan tertentu tentang murah dan mahal dapat dipastikan. Hal tersebut ada yang mengaturnya. Prinsipnya tidak bisa diketahui. Murah karena bukan melimpahnya makanan, demikian juga mahal bukan karena kelangkaan makanan. Murah dan mahal merupakan ketentuan Allah (sunnatullah). Kadang-kadang makanan sangat sedikit, tetapi harganya murah. Pernyataan ini secara implisit bahwa harga bukan hanya ditentukan oleh penawaran, tetapi juga permintaan terhadap barang tersebut. (Yusuf, 1998: 48)

Bahkan Abu Yusuf mengindikasikan adanya variabel lain yang juga turut mempengaruhi harga misalnya jumlah uang beredar di negara lain itu, Penimbunan atau penahanan suatu barang, atau lainnya. Pada dasarnya pemikiran Abu Yusuf ini merupakan hasil observasi terhadap fakta empiris, sering kali terjadi melimpahnya barang ternyata diikuti dengan tingginya tingkat harga, sementara kelangkaan barang diikuti dengan harga yang rendah.

\section{Evolusi Pasar Menurut Al-Ghazali (1058-1111 M)}

Al-Ghazali dalam karyanya Ihya' Al-Ulumuddin juga membahas topik ekonomi, termasuk pembahasan tentang pasar. Dalam magnum opusnya ia telah membicarakan barter dan permasalahannya, pentingnya aktifitas perdagangan dan evolusi terjadinya pasar, termasuk bekerjanya kekuatan permintaan dan 
penawaran dalam mempengaruhi harga. Dalam penjelasannya tentang proses terbentuknya suatu pasar ia menyatakan:

Dapat saja petani hidup di mana alat-alat pertanian tidak tersedia. Sebaliknya, pandai besi dan tukang kayu hidup di mana lahan pertanian tidak ada. Namun, secara alami mereka akan saling memenuhi kebutujan masing-masing. Dapat saja tukang kayu membutuhkan makanan, tetapi petani tidak membutuhkan alat-alat tersebut. Keadaan ini menimbulkan masalah. Oleh karena itu, secara alami pula orang akan terdorong untuk menyediakan tempat penyimpanan alat-alat di suatu pihak, dan penyimpanan hasil pertanian di pihak lain. Tempat inilah yang kemudian didatangi pembeli sesuai dengan kebutuhannya masing-masing sehingga terbentuklah pasar. Petani, tukang kayu dan pandai besi yang tidak dapat langsung melakukan barter juga terdorong pergi ke pasar ini. Bila di pasar juga tidak ditemukan orang yang mau melakukan barter, maka ia akan menjual kepada pedagang dengan harga yang relatif murah, untuk kemudian disimpan sebagain persediaan. Pedagang kemudian menjualnya dengan suatu tingkat keuntungan. Hal ini berlaku untuk setiap jenis barang. (Al-Ghazali: 1997: 227)

Berdasarkan pernyataan tersebut, Al-Ghazali menyadari kesulitan yang timbul akibat sistem barter yang dalam istilah ekonomi modern disebut double coincidence, dan karena itu diperlukan suatu pasar. Selanjutnya, ia juga memperkirakan kejadian ini akan berlanjut dalam skala yang lebih luas, mencakup banyak daerah atau negara. Selanjutnya ia menyadari bahwa kegiatan perdagangan memberikan nilai tambah terhadap barang-barang karena perdagangan membuat barang-barang dapat dijangkau pada waktu dan tempat yang tepat.

Al-Ghazali tidak menolak kenyataan bahwa mencari keuntungan merupakan motif utama dalam perdagangan. Namun, ia memberikan banyak penekanan kepada etika dalam bisnis, di mana etika ini diturunkan dari nilai-nilai Islam. Keuntungan yang sesungguhnya adalah keuntungan yang akan diperoleh di akherat kelak. Ia juga menyarankan adanya peran pemintahan dalam menjaga keamanan jalur perdagangan dami kelancaran perdagangan dan pertumbuhan.

Bentuk kurva permintaan yang berlereng negatif dan bentuk kurva penawaran yang berlereng positif telah mendapatkan perhatian yang jelas dari AlGhazali, meskipun tidak dinyatakan secara eksplisit. Ia menyatakan," Pertanyaan ini sebenarnya sama dengan kurva penawaran itu, bentuk kurva permintaan yang 
berlereng negatif secara implisit tampak dalam pernyataannya bahwa harga dapat diturunkan dengan menambah permintaan." Yang lebih menarik, konsep yang sekarang disebut dengan elastisitas permintaan ternyata telah dipahami oleh AlGhazali. Hal ini tampak jelas dari perkataannya bahwa mengurangi margin keuntungan dengan menjual harga yang lebih murah akan meningkatkan volume penjualan, dan ini pada gilirannya akan meningkatkan kuntungan.

Dalam pandangan Al-Ghazali, pasar harus berfungsi berdasarkan etika dan moral para pelakunya. Secara khusus, ia memperingatkan larangan mengambil keuntungan dengan cara menimbun makanan dan barang-barang kebutuhan dasar lainnya. Penimbunan barang merupakan kezaliman yang besar, terutama di saat-saat terjadi kelangkaan.

Al-Ghazali menganggap bahwa iklan palsu sebagai salah satu kejahatan pasar yang harus dilarang. Lebih jauh, ia memperingatkan para pedagang agar tidak memberikan informasi yang salah mengenai berat, jumlah atau harga barang penjualannya. Pemberian informasi yang salah tersebut merupakan bentuk penipuan yang harus dilarang keras. Iklan-iklan yang bersifat informatif dan tidak berlebihan bisa terima. Ia juga menekankan kebenaran dan kejujuran dalam bisnis. Oleh karean itu, ia mengutuk praktek-praktek pemalsuan, penipuan dalam mutu barang dan pemasaran, serta pengendalian pasar melalui perjanjian rahasia dan manipulasi harga. (Al-Ghazali, 1973: 351)

\section{Pasar Menurut Pemikiran Ibnu Taimiah}

Pemikiran Ibnu Taimiah mengenai mekanisme pasar banyak dituangkan dalam karyanya, yaitu Al-Hisbah fi Al-Islam dan Majmu' Fatawa. Pandangan Ibnu Taimiah mengenai hal ini sebenarnya terfokus pada masalah pergerakan harga yang terjadi pada masa itu, tetapi ia letakkan dalam kerangka mekanisme pasar. Secara umum, beliau telah menunjukkan the beauty of market (keindahan mekanisme pasar sebagai mekanisme ekonomi), disamping segala kelemahannya. Ibnu Taimiah berpendapat bahwa kenaikan harga tidak selalu disebabkan oleh ketidakadilan (zulm/injustice) dari para pedagang atau penjual, sebagaimana banyak dipahami orang pada waktu itu. Ia menunjukkan bahwa harga merupakan interaksi hukum permintaan penawaran yang berbentuk karena berbagai faktor 
yang komplek. Dalam Al-Hisbahnya, Ibnu Taimiah membantah anggapan ini dengan mengatakan:

"Naik turunnnya harga tidak selalu disebabkan oleh adanya ketidakadilan dari beberapa bagian pelaku transaksi. Terkadang penyebabnya adalah defisiensi dalam produksi atau penurunan terhadap barang yang diminta, atau tekanan jiwa. Oleh karena itu, jika permintaan terhadap barangbarang tersebut naik sementara ketersediaannya/penawarannya menurun, maka harganya kan naik. Sebaliknya, jika ketersediaan barang-barang menail dan permintaan terhadapnya menurun, maka harga barang tersebut akan turun juga. Kelangkaan (scarcity) dan keberlimpahan (abudance) barang mungkin bukan disebabkan oleh tindakan sebagian orang, kadang-kadang disebabkan karena tindakan yang tidak adil atau juga bukan. Hal ini adalah kehendak Allah yang telah menciptakan keinginan dalam hati manusia." (Ibnu Taimiah, 1998: 583)

Dalam Fatwanya Ibnu Taimiah juga memberikan penjelasan yang lebih rinci tentang beberapa faktor yang mempengaruhi permintaan, dan tingkat harga. Beberapa faktor itu adalah:

a. Keinginan orang (raghabah) terhadap barang sering kali berbeda-beda. Perbedaan ini dipengaruhi oleh berlimpah atau berlakunya barang yang diminta tersebut.Suatu barang akan lebih disukai apabila ia langka daripada tersedia dalam jumlah yang berlebihan.

b. Jumlah orang yang meminta juga mempengaruhi harga. Jika jumlah orang yang meminta suatu barang besar, maka harga akan relatif tinggi dibanding dengan yang meminta jumlahnya sedikit.

c. Harga juga akan dipengaruhi oleh kuat atau lemahnya kebutuhan terhadap barang, selain juga besar dan kecilnya permintaan. Jika kebutuhan terhadap suatu barang kuat dan berjumlah besar, maka harga akan naik lebih tinggi dibandingkan dengan kebutuhannya lemah dan sedikit.

d. Harga juga akan bervariasi menurut kualitas pembeli barang tersebut. Jika pembeli ini merupakan orang kaya dan terpercaya (kredibel) dalam membayar kewajibannya, maka kemungkinan ia akan memperoleh tingkat harga yang lebih rendah dibandingkan dengan orang yang tidak kredibel (suka menunda kewajiban dan mengingkarinya) 
e. Tingkat harga juga dipengaruhi oleh jenis uang pembayaran yang digunakan dalam transaksi jual beli. Jika uang yang digunakan adalah uang yang diterima luas, maka kemungkinanharga akan lebih rendah jika dibandingkan dengan menggunakan uang yang kurang diterima luas.

f. Tujuan dari suatu transaksi harus menguntungkan penjual dan pembeli. Jika pembeli memilki kemampuan untuk membayar dan dapat memenuhi semua janjinya, maka transaksi akan lebih lancar dibandingkan dengan pembeli yang tidak memiliki kemampuan membayar dan mengingkari janjinya. Obyek dari suatu transaksi adalah terkadang (secara fisik) nyata atau juga tidak. Tingkat harga barang yang lebih nyata (secara fisik) akan lebih rendah dibandingkan dengan yang tidak nyata. Hal sama dapat diterapkan untuk pembeli yang kadang-kadang mereka tidak memiliki uang cash dan ingin meminjam. Harga pada kasus yang pertama kemungkinan lebih rendah dari pada yang kedua.

g. Kasus yang sama dapat diterapkan pada orang yang menyewakan suatu barang. Kemungkinan ia berada pada posisi sedemikian rupa sehingga penyewa dapat memperoleh manfaat dengan tanpa (tambahan) biaya apa pun. Namun, kadang-kadang penyewa tidak dapat memperoleh manfaat ini jika tanpa tambahan biaya, misalnya seperti yang terjadi di desa yang dikuasai penindas atau perampok, atau di suatu tempat diganggu oleh binatang pemangsa. Sebenarnya, harga (sewa) tanah seperti itu tidaklah sama dengan harga tanah yang membutuhkan biaya tambaban.

Pernyataan diatas sesungguhnya menunjukkan kompleksitas penentu harga di pasar. Pada pion (a) Ibnu Taimiah secara implisit menunjukkan peran ekspektasi terhadap permintaan, kemudian terdapat harganya. Menurutnya, keinginan seseorang terhadap suatu barang dipengaruhi oleh ketersediaan barang tersebut. Jika ketersediaan suatu barang langka, maka masyarakat khawatir bahwa esok kemungkinan akan lebih langka sehingga mereka berusaha untuk meningkatkan permintaannya saat ini. Selanjutnya, harga juga akan meningkat jika jumlah orang yang meminta banyak, demikian pula sebaliknya. Pernyataan ini merupakan logika yang amat jelas tentang hubungan kuantitas yang diminta dengan tingkat harga. Pada poin (b) juga mengindikasikan pengaruh aggregate 
demand terhadap harga. Pada poin (c) ditunjukkan bahwa barang yang amat dibutuhkan akan menimbulkan permintaan kuat terhadapnya sehingga harganya cenderung tinggi. Barang-barang seperti ini berarti tingkat substiusinya rendah.

Pernyataan pada poin (d) menunjukkan analisis Ibnu Taimiah pada transaksi kredit. Jika konsumen kaya dan kredibel, maka kepastian pembayaran akan lebih tinggi sehingga harga akan lebih rendah jika keadaan konsumen adalah sebaliknya. Jika konsumen miskin dan tidak kredibel, maka kemungkinan ia menunda atau mengingkari pembayaran akan lebih besar terjadi. Jadi, di sini secara implisit Ibnu Taimiah sebenarnya memasukkan premi resiko dalam komponen pembentukan harga. Semakin kredibel seorang konsumen, maka semakin rendah premi resikonya sehingga harganya jauh lebih rendah, demikian sebaliknya. Pembahasannya tentang premi resiko ini juga tampak jelas dalam poin (f), di mana ia juga menyebutkan sola kapasitas fisik dari barang yang diperjualbelikan sebagai pembentuk harga. Jika harga yang ditransaksikan tidak jelas wujud fisiknya, maka harga juga akan lebih tinggi sebab harus ada premi resiko yang lebih besar pula.

Masalah penggunaan jenis uang juga dapat mempengaruhi tingkat harga. Transaksi yang menggunakan uang yang diterima luas (naqd ra'ij) dapat menghasilkan harga yang lebih rendah. Istilah naqd ra'ij sama dengan pengertian hard currencies (mata uang kuat) pada saat ini. Dengan menggunakan hard currencies, maka risiko instabilitas nilai uang akan lebih kecil dibandingkan menggunakan soft currencies (mata uang lemah) sehingga risiko kesalahan dalam transaksi bisa diperkecil. (Islahi, 1988: 139-149). Pada masa itu, di Damaskus mata uang dirham (mata uang perak) lebih umum diterima, sementara uang dinar (emas) tidak banyak dipakai sebagai uang. Disamping, faktor-faktor yang telah disebutkan dalam point (a) hingga (f). Ibn Taimiah memasukkan kemungkinan adanya biaya tambahan (additional cost) dalam transaksi sehingga mempengaruhi harga. Jika terdapat biaya tambahan, maka wajar jika tingkat harga akan semakin tinggi, demikian pula sebaliknya.

Menurut Ibnu Taimiah, terdapat beberapa syarat atau kondisi agar pasar menjadi sehat. Beberapa syarat atau kondisi tersebut adalah sebagai berikut: 
1. Larangan dalam hal pemaksaan orang untuk menjual barang yang tidak diharuskan untuk menjualnya atau sebaliknya

2. Larangan kolusi antara pembeli dan penjual.

3. Melarang pemalsuan produk serta penipuan pengemasan produk untuk dijual.

4. Standarisasi izin dalam jual beli.

5. Menentang peraturan yang berlebihan ketika kekuatan pasar secara bebas bekerja untuk menentukan harga yang kompetitif, dengan tetap memperhatikan pasar tidak sempurna.

Ibnu Taimiah merekomendasikan bahwa bila penjual melakukan penimbunan dan menjual pada harga yang lebih tinggi dibandingkan dengan harga yang normal, padahal orang-orang membutuhkan barang ini, maka penjual diharuskan untuk menjualnya pada tingkat ekuivalen. Secara kebetulan, konsep ini bersinonim dengan apa yang disebut harga yang adil. Lebih jauh, bila ada elemenelemen monopoli (khususnya dalam pasar bahan makanan dan kebutuhan pokok lainya), maka pemerintah harus turun tangan melarang kekuatan monopoli.

Ibnu Taimiah membedakan antara peningkatan harga yang disebabkan oleh kekuatan-kekuatan pasar dan yang disebabkan oleh ketidakadilan, misalnya penimbunan. Ibnu Taimiah adalah pendukung kuat pengendalian harga dalam kasus ketidaksempurnaan di pasar, tetapi dia menentang pengendalian jika kenaikan harga disebabkan oleh kekuatan-kekuatan pasar murni, yakni permintaan dan penawaran.

Ibnu Taimiah secara umum sangat menghargai arti penting harga yang terjadi karena mekanisme pasar yang bebas. Untuk itu, secara umum ia menolak segala campur tangan untuk menekan atau menetapkan harga (price intervention) sehingga menganggu mekanisme yang bebas. Sepanjang kenaikan atau penurunan permintaan dan penawaran disebabkan oleh faktor-faktor alamiah, maka dilarang melakukan intervensi pasar. Intervensi hanya dibenarkan pada kasus spesifik dan dengan persyaratan yang spesifik pula, misalnya adanya penimbunan sejumlah barang (ikhtikar).

4. Mekanisme Pasar menurut Ibnu Khaldun

jsh Jurnal Sosial Humaniora, Vol 5 No.1, Jun 
Pemikiran Ibnu Khaldun tentang pasar termuat dalam buku yang menumental, Al-Muqaddimah, terutama dalam bab "harga-harga di kota-kota". Ia membagi barang-barang menjadi dua kategori, yaitu barang pokok dan barang mewah. Menurutnya, jika suatu kota berkembang dan jumlah penduduknya semakin banyak, maka harga barang pokok akan menurun sementara harga barang mewah akan mengalami kenaikan. Hal ini, lebih disebabkan oleh meningkatnya penawaran bahan pangan dan barang pokok lainnya sebab barang ini sangat penting dan dibutuhkan oleh setiap orang sehingga pengadaannya akan diprioritaskan. (Ibnu Khaldun: 231). Sementara itu, harga barang mewah akan naik sejalan dengan meningkatnya gaya hidup yang mengakibatkan peningkatan barang mewah.

Ibnu Khaldun sebenarnya menjelaskan pengaruh permintaan dan penawaran terhadap tingkat harga. Secara lebih rinci ia juga menjelaskan pengaruh persaingan di antara para konsumen dan meningkatnya biaya-biaya akibat perpajakan dan pungutan-pungutan lain terhadap tingkat harga.

Pengaruh tinggi rendahnya tingkat keuntungan terhadap perilaku pasar, khususnya produsen, juga mendapat perhatian dari Ibnu Khaldun. Menurutnya, tingkat keuntungan yang wajar akan mendorong tumbuhnya perdagangan, sementara tingkat keuntungan yang wajar akan mendorong tumbuhnya perdagangan, sementara tingkat keuntungan yang terlalu rendah akan membuat lesu perdagangan. Para pedagang dan produsen lainnya akan kehilangan motivasi bertransaksi. Sebaliknya, jika tingkat keuntungan terlalu tinggi perdagangan juga akan melemah sebab akan menurunkan tingkat permintaan konsumen.

(Muhammad, 2004: 261)

Ibnu Khaldun sangat menghargai harga yang terjadi dalam pasar bebas, namun ia tidak mengajukan saran kebijakan pemerintah untuk mengelola harga. Ia lebih banyak memfokuskan kepada faktor yang mempengaruhi harga. Hal ini tentu saja berbeda dengan Ibnu Taimiah yang dengan tegas menentang intervensi pemerintah sepanjang pasar berjalan dengan bebas dan normal. 


\section{Peranan Pemerintah Dalam Pengawasan Pasar}

Untuk lebih menjamin berjalannya mekanisme pasar secara sempurna peranan pemerintah sangat penting. Rasulullah SAW sendiri telah menjalankan fungsi sebagai market supervisor atau al-hisbah, yang kemudian banyak dijadikan acuan untuk peran negara terhadap pasar. Sementara dalam bukunya Al-Hisbah fi Al-Islam, Ibnu Taimiah banyak mengungkap tentang peranan Al-Hisbah pada masa Rasulullah SAW. Rasulullah SAW sering melakukan inspeksi ke pasar untuk mengecek harga dan mekanisme pasar. Seringkali dalam inspeksinya beliau menemukan praktek bisnis yang tidak jujur sehingga beliau menegurnya. Rasulullah juga telah memberikan banyak pendapat, perintah maupun larangan demi sebuah pasar yang bermoral. (Ibnu Taimiah, 1999: 5-10)

Al-Hisbah adalah nama lembaga yang berfungsi untuk memerintahkan kebaikan sehingga menjadi kebiasaan dan melarang hal yang buruk ketika hal itu telah menjadi kebiasaan umum. Sementara tujuan dari Al-Hisbah adalah untuk memerintahkan kebaikan dan mencegah keburukan di pasar.

Al-Hisbah tetap banyak didirikan sepanjang bagian terbesar dunia Islam, bahkan di beberapa negara institusi ini tetap bertahan hingga awal abad ke-20 M. Selama periode, dinasti Mamluk Al-Hisbah memiliki peranan penting, terbukti dengan sejumlah kemajuan ekonomi yang dicapai pada masa itu. Di Mesir, AlHisbah tetap bertahan sampai pada masa pemerintahan Muhammad Ali (18051849 M). Bahkan di Maroko hingga awal abad ke-20, institusi ini masih dapat dijumpai. Di Romawi Timur, yang telah melakukan kontak dengan dunia Islam juga mengadopsi istilah ini dengan sebutan Mathessep yang berasal dari kata muhtasi.(Ibnu Taimiah, 1999: 25)

Pada pemikiran ekonomi kontemporer, eksistensi Al-Hisbah sering kali dijadikan acuan bagi fungsi negara terhadap perekonomian, khususnya dalam pasar. Namun, elaborasi Al-Hisbah dalam kebijakan praktis ternyata terdapat berbagai bentuk. Beberapa ekonom berpendapat bahwa Al-Hisbah akan diperankan oleh negara secara umum melalui berbagai institusinya. Sementara itu, sebagian lainnya berpendapat perlunya dibentuk lembaga khusus yang bernama Al-Hisbah. Jadi, Al-Hisbah adalah sebuah lembaga yang mengatur dan mengawasi 
lancar dan tidaknya aktifitas perekonomian. Bahkan lembaga ini merupakan suatu agen independen sehingga terlepas dari kepentingan kelompok tertentu atau pemerintah itu sendiri. Namun, dengan melihat fungsi Al-Hisbah yang luas dan strategis ini, tampak bahwa fungsinya akan melekat pada fungsi pemerintahan secara keseluruhan, di mana dalam teknis operasionalnya akan dijalankan oleh kementerian, departemen, dinas atau lembaga lain yang terikat.

\section{Kesimpulan}

Pasar adalah sebuah mekanisme pertukaran produk baik berupa barang maupun jasa yang alamiah dan telah berlangsung sejak awal peradaban manusia. Islam menempatkan pasar pada kedudukan yang penting dalam perekonomian. Rasulullah SAW sangat menghargai harga yang dibentuk oleh mekanisme pasar sebagai harga yang adil. Beliau menolak adanya suatu intervensi harga seandainya perubahan harga terjadi karena mekanisme pada yang wajar yaitu hanya karena pergeseran permintaan dan penawaran.

Pasar telah mendapat perhatian memadai dari ulama klasik seperti Abu Yusuf, Al-Ghazali, Ibnu Taimiah dan Ibnu Khaldun. Pemikiran tentang mekanisme pasar tidak saja mampu memberikan analisa yang tajam tentang apa yang terjadi pada masa itu, tetapi tergolong modern untuk masa sekarang. Banyak dari pemikiran mereka baru dibahas oleh para ekonom barat ratusan tahun kemudian.

\section{Daftar Pustaka}

Al-Hamsyari, Musthafa, (1985), Al-Nidham Al-Iqtishad Fi Islam Min 'Ahdi Bi'sah Ila Nihayati Bani Umayah, Riyadh: Dar Ulum.

Enginer, Ashghar Ali, (1999), Asal-Usul dan Perkembangan Islam Analisi Pertumbuhan Sosioekonomi, Yogyakarta: Pustaka Pelajar.

Al-Audhi, Rifaat, (1987), Min Al-Turast: Iqtishad li Al-Muslimin, Makkah: Rabithah Alam Islami

Yusuf, Abu, (1998), Kitab Al-Kharaj, Beirut: Dar Al-Ma'arif.

Al-Ghazali, Abu Hamid, (1997) Ihya' Ulum Al-Din, Beirut: Dar Nadwah. 
32 - Memahami Mekanisne Pasar Dalam Ekonomi Islam

Al-Ghazali, Abu Hamid, (1997), Kimiya Al-Sa'adat, Lahore: Naashraan Quran

Ltd.

Ibnu Taimiah, (1998), Majmu' Fatawa Shaikh Al-Islam Ahmad Ibn Taimiah,

Riyadh: Al-Riyadh Press.

Ibnu Taimiah, (1999), Al-Hisbah fi Al-Islam, Kairo: Dar Al-Sha'ab.

Islahi, Abdul Azim, (1988), Economic Concepts of Ibn Taimiah, Leicester: the

Islamic Foundation.

Ibnu Khaldun, (1995), Al-Muqaddimah, Beirut: Dar Kutub Ilmiah.

Muhammad, (2004), Ekonomi Mikro dalam Prespektif Islam, Yogyakarta: BPFE

Yogyakarta. 
jsh Jurnal Sosial Humaniora, Vol 5 No.1, Juni 2012 